\title{
NUDT1 Gene
}

National Cancer Institute

\section{Source}

National Cancer Institute. NUDT1 Gene. NCI Thesaurus. Code C49205.

This gene plays a role in the hydrolysis of oxidized nucleotides. 